\title{
The Impact of World Recession and World Prices on a Sample of Developing Countries
}

\author{
Charles Harvey
}

\section{Background}

This article is based on a recently completed study' of changes in the global economy and their impact on a sample of 11 countries. There were 10 developing countries in the sample - Argentina. Brazil, Jordan, Korea. Kuwait. Malawi. Sri Lanka, Tanzania, Tunisia and Venezuela - and one peripheral European country, Ireland. The countries were chosen to include net exporters and importers of oil, manufactured goods and food, and to include a spread of income levels and location. Not all of the conclusions of the study can be summarised here: this paper concentrates on the post-1979 recession. its impact on the sample countries' development and rates of inflation, and the success of their policies. in so far as success can be addressed. ${ }^{2}$

The first point to stress is that the post-1979 recession was very much more severe, and went on for much longer, than the post -1973 recession. This was in large part because of the different reactions after 1979 of the OECD governments. ${ }^{3}$ In 1974 there was considerable collective concern to avoid global deflation, and positive action was taken, for example large increases in the flow of aid and the creation of new lending facilities at the IMF.

There was nothing comparable after 1979. On the contrary, the overriding concern to control inflation,

\footnotetext{
${ }^{1}$ Stephany Griftith-Jones and Charles Harvey (eds), World Prices and Development, Gower, forthcoming 1985. The study was sponsored by the Kuwait Fund for International Development and the OPEC Fund. The help of the contributors and sponsors is gratefully acknowledged, especially that of my co-editor Stephany Griffith-Jones.

2. In this short paper, the point that countries and their governments are not identical is neglected, as is the point that governments are not monolithic nor representative of all groups of people in a country.

${ }^{3}$ The World Bank gives two proximate causes of the post-1979 recession: the 1979 oil price rise and the disinflationary policies of the governments of most major industrial countries after 1980, but adds that there was an underlying long term deterioration in the economic performance of industrial countries (World Development Report. 1984: 11-12).
}

and the method chosen (reduced monetary growth) tended to deepen and lengthen the recession. There was an al most complete neglect of the effect of OECD policies on developing countries. The only significant exception was when the financial system was threatened by the prospect of default by large borrowers from Western banks.

Meanwhile, as is detailed below, developing countries did not share in the one benefit of the prolonged recession: in general inflation did not fall in developing countries, and where it did fall it was not reduced to anywhere near the low levels of the major OECD economies, still less the fall in the level of import prices.

The effect on developing countries of the post-1979 recession was made much worse because so many governments expected it to be short, as had been the case in the post-1973 period. This expectation was enhanced by the repeated forecasts of official bodies - including the OECD. the IMF and the World Bank - that the world economy would soon recover. Whatever the reason, many developing country governments ran down their reserves and rapidly increased their short term foreign debt. These policies might have been the right ones if the world economy had indeed recovered quickly. But they were extremely damaging in the event; and the effects were worsened by the very large increase in real international interest rates, from having been mainly negative to the highest levels seen since 1945

As a result, a wide range of developing countries were in deep financial and economic trouble in the early 1980s, including some of those exporting (or selfsufficient in) oil or food, and including those which had followed a wide range of different policies. Judgements as to whether particular categories of country or of policy were 'successful' or not had therefore to be more subjective than if the international economy had not inflicted a degree of failure on both the "successful" and the "unsuccessful'.

IDS Bulletin, 1985, vol 16 no 1, Institute of Development Studies, Sussex 


\section{Impact on Output and Debt}

With the exception of Kuwait, all the countries in the sample maintained growth of output in the period 1973-75. Malawi, and to a lesser extent Ireland, faltered somewhat, but both recovered in the 1975-79 period. Indeed, in the four years after the 1975 recession, real output in all the countries except Argentina grew rapidly. After 1979, country after country ran into serrious trouble. Some managed to maintain output growth for longer than others, but that was not necessarily an advantage if it depended on unsustainable short term borrowing and resulted in a more disruptive crisis at a later date.

Falls in output were not the only indicators of crisis. Of the sample countries, Argentina, Brazil, Malawi and Venezuela had to reschedule their external debts, and the first three had to submit to IMF-imposed cutbacks in demand as well. In Malawi this occurred despite a falling real wage in the 1970s and early 1980s. Tanzania was in such a serious state that any reasonable projection of export earnings and resource transfers pointed to a continuing decline. Sri Lanka cut back on much of its welfare system; and even Tunisia, a net oil exporter, having been able to maintain growth in 1980 and 1981 , was in some financial difficulty by 1983 .

Only Ireland, Korea, Kuwait and Jordan were not in immediate trouble by the end of 1983. Ireland was able to increase official external debt to over 50 per cent of GDP without becoming less creditworthy, helped no doubt by its status as a developed industrial country (and despite being the poorest in this category). Ireland was also helped by having access to the EEC market, while other industrialising countries faced increased protection (to Ireland's advantage).

Kuwait had such a high income, from oil and from the foreign investment of past surpluses, that its economy was able to ride out comfortably the fluctuations so far occurring in the world economy. And Jordan was so closely linked to the income of nearby oil exporters, through aid and migrant workers' remittances, as to be relatively immune to the effects of the world recession.

It is rather more difficult to explain why Korea was able to resume growth after only one year in which output fell, and to sustain its ability to obtain loans from international banks, in contrast to Brazil for example. Both countries had exceptionally rapid growth of export earnings, and maintained similar ratios of foreign exchange reserves to imports, between 1978 and 1981. Although Brazil financed a higher proportion of imports with foreign loans in this period, Korea financed more of its investment with foreign borrowing.
The explanation of Brazil's financial crisis must lie partly in the sheer size of the country's external debt and debt service ratio ( $\$ 90 \mathrm{bn}$ and 86 per cent respectively in 1982), partly in the greater external shocks suffered from falling terms of trade and rising international interest rates, and maybe partly also because Brazil was regarded by the international banks as part of the Latin American debt problem when Mexico defaulted in 1982. Korea, on the other hand, managed to reduce its debt service ratio (and its ratio of total external debt to exports), and suffered a much smaller external shock - partly because Korea is an importer of commodities and gained instead of losing from the fall in commodity prices in the early 1980s.

Both Korea and Brazil chose a high risk strategy, based on large scale foreign borrowing invested in rapid growth; it would seem that Brazil took the higher risks and then suffered the greater external shocks. Nevertheless, even for Brazil the strategy yielded two decades of five per cent growth in income per head.

\section{Access to Oil Exporters' Income}

An important feature of adjustment for oil importing countries was their ability to take advantage of the new opportunities created in the oil exporting countries by the large shift of income in their favour. Ways of earning additional income from oil exporters included exporting to them, bidding for construction contracts in them, sending migrant workers to them, and receiving OPEC aid. Some countries also borrowed from international banks, whose resources included some of the unspent balances of the oil exporters. The only countries in the sample which did not benefit significantly from any of these sources were Malawi and Tanzania.

Brazil and Korea were the only countries in the group to respond on a large scale to the increased demand from oil exporters for manufactured goods, and in particular for capital goods. Korea's exports of heavy manufactures (to all countries) increased from 14 per cent to 43 per cent of total merchandise exports between 1971 and 1981, so that Korea was able to take full advantage of the new situation: Korean exports to oil exporting countries rose by 230 per cent from 1978 to 1981, compared with 126 per cent for total Korean exports. Korea was also the only country in the sample to benefit from the construction boom in oil exporting countries: receipts from overseas construction jumped from $\$ 39 \mathrm{mn}$ in 1975 to $\$ 2,148 \mathrm{mn}$ in 1978 .

The structure of Brazil's exports did not change quite so fast - the share of transport and machinery equipment rose from almost nothing in 1960 to 17 per 
cent in 1980 - but nevertheless Brazil's exports to oil exporters also increased by over 200 per cent from 1977 to 1981 , compared with a 92 per cent rise in total Brazilian exports.

The contrast with other countries in the sample was very marked. The share of exports from Argentina and Sri Lanka going to oil exporters actually went down from 1977 to 1981. Jordan continued to sell a high proportion of exports to oil exporters, but merchandise exports were a fairly minor source of foreign exchange compared to aid and remittances. Ireland and Tunisia (itself a net oil exporter) increased their sales to oil exporters, but not by significant amounts. Venezuela, as a major oil exporter, did not have the same urgent need to sell to other oil exporters. But as a middle income country it could have used the chance of diversifying its economy. It failed to do so, exports to oil exporters being insignificant throughout $(0.1 \mathrm{per}$ cent in 1977 and 0.2 per cent in 1980).

Jordan, and to a much lesser extent Sri Lanka, were the two countries in the sample to send large numbers of migrant workers to oil exporting countries. In the case of Jordan, migrant workers' remittances rose from $\$ 16 \mathrm{mn}$ in 1970 to $\$ 1,047 \mathrm{mn}$ in 1981 , and from 47 per cent to 141 per cent of earnings from merchandise exports. Jordan obviously gained from nearness to the Middle East oil exporters, and also from the above average level of education of Jordanians, so that workers were able to get jobs at skilled as well as unskilled levels.

Sri Lanka also increased its earnings from this source, though not on such a dramatic scale as Jordan. Migrant workers' remittances to Sri Lanka rose from $\$ 3 \mathrm{mn}$ to $\$ 230 \mathrm{mn}$ over the same period, and from one per cent to 22 per cent of the level of merchandise exports. Korea quadrupled its receipts from migrant workers over the same 11 years, but, because of the even more rapid increase in exports, remittances were only one per cent of exports in 1981. Of the other countries in the sample, only Tunisia and Malawi sent many migrant workers to other countries, but Tunisians went mainly to France and Malawians mainly to South Africa.

Jordan was also the main recipient of OPEC aid among the sample countries. OPEC aid to Jordan was $\$ 911 \mathrm{mn}$ in 1981 , very nearly as much as receipts from migrant workers and therefore also considerably more than earnings from exports of goods. As already noted, Jordan depended so completely on migrant remittances and aid from neighbouring oil exporters, that its fortunes varied more with those of the oil exporting countries than with those of other oil importers. And when the oil price began to fall in the early 1980s, Jordan lost more from reduced foreign exchange receipts than it gained from cheaper imports of oil. OPEC aid to Jordan, for example, fell from $\$ 932 \mathrm{mn}$ in 1980 to $\$ 709 \mathrm{mn}$ in 1982 .

Tunisia (consistently) and Sri Lanka and Tanzania (at times) also received some OPEC aid, but on a very much smaller scale. In 1982, OPEC aid to these three countries was in total only seven per cent of OPEC aid to Jordan. Again, the flows diminished after 1980 (except to Tanzania because of one large project).

The major borrowers from commercial banks among developing countries in the sample were Brazil, Korea, Argentina and Venezuela. Jordan, Malawi, Sri Lanka, Tanzania and Tunisia borrowed very little from commercial banks, and Kuwait nothing at all. Not all the major borrowers had a debt crisis, Korea being the exception; and not all the minor borrowers managed to avoid one. Malawi had to reschedule external debts, and Tanzania ran up massive arrears of import payments, an even less satisfactory form of debt.

Of the major borrowers, Brazil and Korea have already been discussed; whatever the final judgement on their chosen strategies, they borrowed in order to invest, and in exportable products, as shown by the rapid growth in their exports. Argentina, on the other hand, when external commercial borrowing began on a large scale in 1977, used the money much less productively. It went mainly to finance a large outflow of private capital, on the one hand, and to pay for imports of goods competitive with Argentinian products, on the other. Investment was low and output stagnated, while inflation and unemployment increased. Venezuela's foreign borrowing was not quite so disastrous, nor was the debt crisis so difficult to resolve as that of Argentina. Nevertheless, much of Venezuela's foreign debt was acquired for unsustainable investment programmes, and at high cost and short repayment terms, because of ineffective regulations; furthermore, it has been estimated that, as for Argentina, a large proportion of the foreign debt financed private capital outflows.

\section{Evaluation of Different Policies}

As noted already, the unforeseen severity and length of the post-1979 recession made it more difficult than it might otherwise have been to distinguish between successful and unsuccessful policies. Nevertheless some points stand out sufficiently to be worth making.

\section{Commitment to structural change}

The case studies seem to show that countries attempting structural change became much more vuinerable to external shocks. Structural change required new investment, sustained over a long period, which in turn required steadily growing import 
capacity. Output from the new investment tended to be delayed - by the learning process needed for the management of new systems, for example. More generally, the difficulties caused by external shocks were undoubtedly compounded by mistaken domestic policies, but such mistakes were almost inevitable because external shocks made management so much more difficult.

Tanzania was caught in just such a trap after 1979 , made worse by neglect of the export sector during the 1970s. Tanzania also made strenuous efforts to protect low income groups from the effect of adjustment, an objective that itself made adjustment more difficult.

Structural change in Malawi was more modest. There was a major shift within the agricultural sector, away from smallholders and in favour of estates. This was achieved by buying from smallholders at low prices and investing much of the marketing board surplus in estates, by forcing banks to lend to estates, and by reducing the outflow of migrant labour so that estates were able to increase their labour force at a declining real wage. Nevertheless Malawi managed to survive the post-1979 recession in considerably better shape than Tanzania, partly at least because of the less ambitious nature of its development strategy - and because Malawi did not neglect (to the same extent) the year by year need to maintain some sort of external balance. The comparative figures for export growth are very striking.

\section{Table 1}

\section{Annual percentage changes in export volume in Malawi and Tanzania}

$$
1960-70
$$

$1970-80$

\begin{tabular}{lrr}
\hline Malawi & $+11.6 \%$ & $+5.9 \%$ \\
Tanzania & $+3.4 \%$ & $-8.1 \%$ \\
\hline
\end{tabular}

Source: World Development Report, 1983

Venezuela also embarked on an ambitious series of investments in large capital and import intensive projects, through corporations directly financed and controlled by the state. This strategy was based on the expectation that foreign exchange would continue to be plentiful for a lengthy period; yet revenues were also committed to consumer subsidies, and to rapid increases in imports while domestic prices were held down. When oil revenue stagnated, the programme was sustained by poorly managed external borrowing, leading eventually to the need for a debt rescheduling.
There is no doubt that fluctuations in the price of oil made economic management very difficult for Venezuela, yet it was striking how much more successfully Tunisia, also a net oil exporter, managed to get through the first part of the post-1979 recession. For example, Tunisia's GDP grew at more than 6 per cent in 1980 and 1981, and at 1.5 per cent in 1982 (GDP in Venezuela fell slightly from 1980-82). Although Tunisia enjoyed the benefits of rises in the prices of both oil and other commodity exports, earnings from both manufactured exports and international tourism also increased enormously. Venezuela, on the other hand, simply allowed oil to rise from 93 per cent to 95 per cent of visible exports, developing no other source of foreign exchange earnings and doing less to increase food production.

It is possible that Tunisia coped more successfully with external fluctuations because it had a level of net oil exports which was not so large as to create a sense of unlimited riches. The third oil exporter in the sample, Kuwait, had such large surpluses of export earnings (and increasingly of income from foreign investments) as to be more or less unaffected by external fluct uations. Venezuela, in contrast, fell somewhere in between: rich enough as a result of oil price rises to attempt overambitious structural change, but not rich enough to sustain it.

\section{Subsidies}

Several of the sample countries used subsidies to protect the population from price increases, including those on imported goods. The case studies suggest some generalisations:

- the prices of subsidised goods tend not to be raised, because the blame would fall on the government rather than on the market;

- the cost of subsidies thus becomes un manageably large;

- the shock of removing subsidies then becomes increasingly impossible to contemplate, politically or economically, because of the size of the price changes involved.

Kuwait appeared to be an exception to these generalisations: the cost of subsidies in Kuwait fluctuated rather than increasing continually. This could be explained by the lack of political influence of the recipients, who were to a large extent migrant workers ( 60 per cent of the Kuwait population in 1981 was non-Kuwaiti).

But the cost of subsidies in Venezuela, Sri Lanka and Tunisia, for example, did grow unmanageably large. And attempts to cut subsidies caused maior problems. Jordan also subsidised some prices, but limited the cost by creating state trading stores selling at lower tax 
free prices to certain privileged groups. As in Kuwait, lower level jobs were being done by immigrants, limiting the demand for increased subsidy, and enabling the programme to continue.

There is much to be said in favour of subsidising the cost of essentials for poor people, especially when, as often occurs, other forms of redistribution are not feasible. The problem was that the cost had a tendency to grow to levels that could not be financed, even by net oil exporters such as Tunisia and Venezuela.

Many of the same arguments apply to allowing the real exchange rate to rise, which is an attractive alternative to subsidies because it does not require government expenditure. As with subsidies, the longer it continues the harder it is to change, as the gap between the current and 'market' price widens.

\section{Energy policies}

Faced with higher oil prices, oil importers could in principle choose between raising the domestic price of oil and reducing demand for other imports by enough to restore external balance, on the one hand; and trying to increase production of exports and import substitutes, to compensate for the increased cost of imports, on the other hand. A crude way of measuring the relative success of such attempts is to compare movements in the ratio of oil imports to export earnings. An above average increase in the ratio would result from not forcing up the oil price, or from adjusting by general restrictions on imports, or from failing to increase exports or domestic energy output.
Sri Lanka's position was not as bad as appears in the table. In 1981, 44 per cent of oil imports were for re-export as refined oil products; and tourism and migrant workers' remittances were developed as major alternative sources of foreign exchange ( 48 per cent of visible export earnings in 1982). These factors would reduce Sri Lanka's ratio in 1982 from 54 per cent to 24 per cent. The latter is not comparable to other figures for 1980 in the table, because other countries had invisible earnings, but is more or less comparable to Sri Lanka's 1970 figure.

Brazil and Tanzania stand out as less successful by this measure than the other sample countries. Brazil's pattern of growth in the 1970s was very much based on cheap energy; the only effective energy policy was the substitution of alcohol for petrol. A new energy plan was launched in 1979, but the measures were too recent for any results to show up in the table.

Tanzania did raise the domestic price of oil, but the share of taxation in the price declined, so that the local price grew by less than the import price. The government wanted to lessen the impact on low income groups - 55 per cent of imported oil was used for public transport, and another 10 per cent for rural lighting and urban cooking. Tanzania's poor performance on this ratio was also caused by the failure of exports to grow, already noted.

Net exporters of oil also had to decide, from a position of much greater strength, whether to raise domest ic oil prices in line with international prices. Both Kuwait

Table 2

\section{Ratio of imported oil to exports}

(percentages)

\begin{tabular}{|c|c|c|c|}
\hline & 1970 & 1982 & $\begin{array}{l}\% \text { change in } \\
\text { ratio } 1970-82\end{array}$ \\
\hline \multicolumn{4}{|c|}{ less than $100 \%$ increase in ratio } \\
\hline Argentina & 18 & 21 & 17 \\
\hline Ireland & 9 & 16 & 78 \\
\hline Jordan & $79^{1}$ & $73^{2}$ & -8 \\
\hline Korea & 15 & 28 & 87 \\
\hline Malawi & 11 & 16 & 45 \\
\hline \multicolumn{4}{|c|}{ more than $100 \%$ increase in ratio } \\
\hline Brazil & 12 & 54 & 350 \\
\hline Sri Lanka & $12^{3}$ & 54 & 350 \\
\hline Tanzania & 9 & $43^{4}$ & 378 \\
\hline
\end{tabular}

Notes: ${ }^{1} 1960 \quad{ }^{2} 1980 \quad{ }^{3} 1973$ "imports of energy

Sources: IFS: Central Bank of Ceylon: World Development Report. 
and Venezuela chose a policy of very cheap domestic energy. In Venezuela, the large scale, energy and capital intensive investments encouraged by cheap domestic energy could not be sustained, and caused severe sectoral and macroeconomic disequilibria. Even in Kuwait, where there was no medium term constraint on sustaining the investment programme, the very rapid growth of domestic energy consumption could cause problems in the long term.

In Tunisia, petrol taxes were used to finance food subsidies. Altholgh this gave some elasticity to food subsidy revenues, the programme still ran short of cash eventually, as already noted. But there was also an overemphasis on energy intensive investment: energy consumption grew faster $(9.2$ per cent) than GDP ( 8.2 per cent) or then energy production $(6.0$ per cent). This was to some extent a measure of success in raising income and in industrialisation; but it was also of concern for the future, because it could cause macroeconomic imbalance and because new products could find themselves unable to compete internationally.

\section{The Control of Imported Inflation}

The phrase 'imported inflation' is usually used to mean the increased costs of imported goods and services, which cause domestic prices to rise (unless the exchange rate increases to compensate). Undoubtedly that occurred in most of the sample countries in 197375 and again in 1979-81. However, the sample countries suffered from externally induced inflation, in the post- 1979 period in particular, in other ways as well, notably:

- global recession plus a decline in the terms of trade can induce a country either to devalue, which raises import prices further, or to control imports, which reduces supply with inflationary effects;

- global recession also reduces government revenue from import and export taxes, causing an inflationary budget deficit;

- externally induced recession pushes up industrial costs as capacity utilisation falls.

In addition, inflation can be transmitted from abroad by a rise in export prices, or by easy access to external borrowing, which increases demand for domestic goods and services (unless it is all invested abroad).

The evidence from the sample countries suggests that recession was a major reason for inflation continuing, sometimes at even higher rates, after the rate of inflation fell back in the developed industrial countries. So the one important gain from the policies of the developed countries, namely the reduction in their rates of inflation, was not shared by developing countries. This is shown quite clearly in Table 3 .
In 1976-78, nearly all the 'low inflation' countries managed to reduce their inflation rates. Malawi and Sri Lanka even managed to get their inflation rates down to pre-1973 levels. The only exceptions were the two oil exporters (there were no pre- 1973 figures for Kuwait) who suffered less inflation in 1973-75, probably because their domestic prices were not affected directly by the oil price.

In contrast, only some countries were able to reduce their inflation rates after 1980, and only Jordan, Kuwait and Korea were able to get their inflation down to or below pre-1979 levels (the decelerators). The other sample countries all had higher inflation after 1980 than they had had before 1979 (the accelerators); and three countries - Ireland, Sri Lanka and Tanzania - actually had higher rates of inflation in 1981-82 than during the $1979-80$ period of high global inflation.

Whatever the mechanisms by which inflation was sustained (and increased) in these countries, the fall in global inflation after 1980 was of little benefit. Certainly none of the sample countries, not even Jordan and Kuwait which avoided all import controls, was able to get down to the low inflation rates of, for example Britain, Japan and the USA, still less to the fall in prices of traded goods (see Table 3 ).

The three countries whose inflation increased after 1980 either devalued (Ireland and Tunisia, by 15 per cent and 27 per cent against the SDR respectively) or controlled imports very severely instead (Tanzania). The other countries which failed to get their inflation down to pre- 1979 levels also fell into one of these categories: Malawi devalued against the SDR by 15 per cent, while Sri Lanka and Venezuela relied on controls.

It is generally true that developing countries give a lower priority to controlling inflation than to growth and the alleviation of poverty. But the policies of the OECD countries after 1979 made growth more difficult, and did not even pass on their one gain, a reduction in inflation. Nor is it possible to see, in most cases, just how the poorer countries could have reduced their inflation in line with the richer countries, because of the severe balance of payments problems created for them by the lengthy recession. No doubt developing country policies could have been improved, but it is hard to see how most of the sample countries could have avoided entirely the need to devalue or curtail imports by other means.

\section{Conclusion}

The task of developing countries, in coping with the effects of the post-1979 recession, was made difficult, 
not just by the recession itself, but by other actions of developed countries, including increased protectionism and exceptionally high real interest. rates. Direct action concerning the developing countries in general, and the poorest ones in particular, was harmful rather than helpful - notably the American refusal to contribute an adequate amount to the IDA replenishment in 1984, the increasing commercialisation and politicisation of bilateral aid, the inadequate increase in IMF quotas, and the failure to increase the real value of aid.

The American Government in particular seemed to be further than ever from taking account of Third World interests; instead it appeared to be moving in the opposite direction, both in its domestic economic decisions and in its influence on such institutions as the IMF and the World Bank, which were forced to fight to defend even the existing levels of finance and freedom of action available to them. One positive sign during the 1970s was the increased share of trade between developing countries in total world trade. This suggested that some developing countries at least might be able to reduce their dependence on events in the industrial countries; but this was mainly significant for middle income exporters of manufactures, and had relatively little to offer the poorer countries. Furthermore, there were indications in the early 1980s that this growth in the share of trade between developing countries had been halted by the post-1979 recession.

Table 3

\section{Rates of inflation 1970-82}

$1970-72$

1973-75

1976-78

1979-80

$1981-82$

\section{GLOBAL AVERAGES}

World export prices

Import prices of oil importers

Industrial country export prices

$\begin{array}{ll}6 & 23 \\ 4 & 25 \\ 7 & 18\end{array}$

\section{low inflation countries:} accelerators ${ }^{1}$

\section{Ireland}

Malawi

Sri Lanka

Tanzania

Tunisia

Venezuela

\section{low inflation countries:} decelerators ${ }^{1}$

Jordan

Korea

Kuwait

9
7
5
5
3
3

16
12
10
18
6
8

13
6
5
10
6
8

$\begin{array}{rr}11 & 14 \\ 15 & 10 \\ 18 & 14 \\ 22 & 27 \\ 9 & 13 \\ 17 & 12\end{array}$

high inflation countries

Argentina

Brazil

\section{1 \\ 13}

8

462

19

20

14

$-2$

$-1$

$-4$

\section{Brazil}

Note: ${ }^{1}$ accelerators and decelerators defined in terms of whether inflation was higher or lower in 1981-82 than in 1976-78, see text below.

Source: International Financial Statistics, consumer price indices. 